INTERNATIONAL JOURNAL OF MULTIDISCIPLINARY RESEARCH AND ANALySis

ISSN(print): 2643-9840, ISSN(online): 2643-9875

Volume 04 Issue 11 November 2021

DOI: 10.47191/ijmra/v4-i11-16, Impact Factor: 6.072

Page No.- 1593-1596

\title{
Age and Weight-Related Variation in Fasting Plasma Glucose among Inhabitants of Enugu Metropolis, Southeast Nigeria
}

\author{
Ogbu, Innocent S. I. ${ }^{1,2}$, Ikpeama Anthony I. ${ }^{2}$, Ogbu, Chinemerem C. ${ }^{1}$, Nwobodo, Emmanuel I. ${ }^{1}$, \\ Odochi, Ogbu C. ${ }^{3}$, Nduka, Okeke J. ${ }^{4}$ \\ ${ }^{1}$ Department of Medical Laboratory Science, Evangel University Akaeze. Ebonyi State. Nigeria \\ ${ }^{2}$ Department of Medical Laboratory Science, University of Nigeria, Enugu Campus. Enugu Nigeria \\ ${ }^{3}$ Department of Physiology, Evangel University Akaeze. Ebonyi State. Nigeria \\ ${ }^{4}$ Department of Chemical Pathology, Faculty of Clinical Medicine. Ebonyi State University. Abakaliki. Ebonyi State. Nigeria
}

\begin{abstract}
:
Aim: Fasting plasma glucose (FPG) is the concentration of plasma glucose after an overnight ( $\leq 8$ hours) fast. It is diagnostic of diabetes mellitus and prediabetes. It is used in the screening of other health conditions and monitoring of treatment of diabetes. It is useful to determine factors that influence FPC for more accurate interpretation of the test.

Procedure: One hundred and fifty (150) apparently healthy subjects aged 1 - 80 years were recruited for the study after an informed consent. Their ages were noted, weight and height measured and body mass index (BMI) calculated. Two milliliters of fasting blood sample were collected from each before 10 am each day and put into fluoride-oxalate bottle. The samples were spun and the plasma analyzed for glucose on the same day using the Glucose oxidase method.

Results. The range of FPG values obtained was $2.3-7.0 \mathrm{mmol} / \mathrm{l}$ and mean age, BMI, and FPG, $( \pm S D)$, were $38.25 \pm 21.86$ years, $26.49 \pm 6.37$ and $4.23 \pm 0.96 \mathrm{mmol} / \mathrm{I}$ respectively. FPG correlated with age $\left(r^{2}=0.4469 ; p=0.0001\right)$ and $B M I\left(r^{2}=0.2271 ; p=0.0001\right)$. FPG differed with age and BMI. 98\% of the subjects had FPG within the range $2.2-6.6 \mathrm{mmol} / \mathrm{l}$ with $72 \%$ falling within the range $3.4-5.5 \mathrm{mmol} / \mathrm{I}$. There was no significant difference between the male and female values though this existed in their BMI, ( $p=0.0178)$.
\end{abstract}

Conclusion. FPG is influenced by both age and BMI of subjects, there is, therefore, the need to take these factors into consideration in the interpretation of results of FPG tests.

KEY WORDS: Fasting plasma glucose; body weight; age; body mass index.

\section{INTRODUCTION}

Fasting blood glucose, (FBG) is the level of glucose in the blood after an overnight ( 8 hours) fast. It is determined in the screening for and diagnosis of disorders of glucose metabolism such as diabetes mellitus, pre-diabetes and in the monitoring the control of diabetes ${ }^{[1]}$. Glucose is a major source of energy for most cell in the body and is required obligatorily by brain cells Concentrations less than $1.7 \mathrm{mmol} / \mathrm{I}$ or greater than $16.7 \mathrm{mmol} / \mathrm{I}$ can produce confusion or unconsciousness ${ }^{[2]}$.

The reference range for blood glucose is $3.3-5.8 \mathrm{mmol} / \mathrm{l}$. Values higher than $6.1 \mathrm{mmol} / \mathrm{l}$ but lower than $7.8 \mathrm{mmol} / \mathrm{l}$ are diagnostic of fasting hyperglycaemia (pre-diabetes). Values $\geq 7.8 \mathrm{mmol} / \mathrm{l}$ are suggestive of diabetes mellitus. FBG could be elevated in health conditions that affect glucose metabolism secondarily such as hyperthyroidism, pancreatitis, pheochromocytoma and excess sugar intake. On the other hand it could be low in hypopituitarism, hypothyroidism and starvation. Drugs can also increase or decrease FBG such as corticosteroids, diuretics, adrenaline oestrogens and acetaminophen, tolazamide, alcohol, etc respectively ${ }^{[3]}$ Blood glucose could be influenced by other factors such as age and body weight and these can complicate the interpretation of results if their influence is not defined in a population. This study examines the variation in FBG due to age and body mass index in an Igbo population of Southeastern Nigeria 


\section{Age and Weight-Related Variation in Fasting Plasma Glucose among Inhabitants of Enugu Metropolis, Southeast Nigeria}

\section{MATERIALS AND METHODS}

One hundred and fifty apparently healthy subjects (men 85) aged between 1 and 80 years were recruited for the study after written informed consent was obtained. They were not diabetic or on drugs that could influence blood sugar levels at the time of sample collection. Patients suffering from diseases like liver disease, renal disease, cardiac disease, respiratory disease or any other acute or chronic diseases as well as patients suffering from AIDS, thyroid disorder, psychiatric illness or on insulin therapy were also excluded. Pregnant women are also not included in the study. The subjects were asked to take their usual diet for three days prior to sample collection. Twenty subjects were recruited in each decade of age except in the $71-80$ years age range with only 10 subjects. For infants and under-age children the parent's consent was obtained before blood sample collection. Blood samples, $(2 \mathrm{ml})$ were collected between $7 \mathrm{am}$ and $10 \mathrm{am}$ each day and put into fluoride-oxalate bottle. Standard method of sample collection was employed ${ }^{[4]}$. The samples were spun and the plasma glucose was analyzed the same day using glucose oxidase/peroxidase method of ${ }^{[5]}$. Results were grouped according to age, BMI and mean FPG for analysis. Data analysis was done using GraphPad Prism version 2. P-value less than 0.05 was considered significant. The data were expressed as mean \pm SD

\section{RESULTS}

The mean age of the subjects was $38.25 \pm 21.86$ years, BMI $26.49 \pm 6.37 \mathrm{~kg} / \mathrm{m}^{2}$ and FPG $4.23 \pm 0.96$. There was a sharp rise in mean FPG after 10 years from 2.9 to $4.1 \mathrm{mmol} / \mathrm{l}$ and a plateau up to the age of 40 years when it rose slightly but significantly to $4.3 \mathrm{mmol} / \mathrm{l}$. Thereafter was a sustained average rise by $0.5 \mathrm{mmol} / \mathrm{I}$ with each decade up to $6.0 \mathrm{mmol} / \mathrm{l}$. (Table 1). Similar rise without a plateau was observed with increase in BMI with average rise of $0.3 \mathrm{mmol} / \mathrm{l}$ per 5 units increase in BMI (Table 2). $98 \%$ of the subjects had FPG within the range $2.2-6.6 \mathrm{mmol} / \mathrm{I}$ with $72 \%$ falling within the range $3.4-5.5 \mathrm{mmol} / \mathrm{l}$. (Table 3 ).

There was no significant difference between the male and female mean FPG values though this existed in their $B M I,(p=0.0178)$. FPG correlated with age $\left(r^{2}=0.4469 ; p=0.0001\right)$ and $B M I\left(r^{2}=0.2271 ; p=0.0001\right)$ and BMI correlated with age. All samples with FPG $\geq 6.0 \mathrm{mmol} / \mathrm{l}$ belonged to subjects aged $\geq 60$ years.

\section{DISCUSSIONS}

The mean BMI found in this study was in the overweight range and is higher in females. This is similar to findings of a previous study in Nigeria ${ }^{[6]}$. Overweight and obesity are consistent parameters associated with cardiovascular risk in most populations ${ }^{[7-}$ ${ }^{9}$. The finding of an average BMI that is in the overweight range suggests a possible interplay of genetic factors, sedentary lifestyle and lack of exercise among subjects. Blood glucose levels showed no significant difference between the males and the females. This is in agreement with work of Onyesom et al ${ }^{[10]}$ among Nigerian undergraduates. However Hossain et al (2017) ${ }^{[11]}$ reported a higher mean value for female undergraduates than their male counterpart. The reason may be found in the report by Mehdad et al ${ }^{[12]}$ where FPG was highly correlated with fat mass (FM) and percentage body fat PBF in overweight-obese girls. They observed significant relationship between FBG and both BMI and WC in overweight-obese girls, while there was no significant association between FBG and other variables in boys and normal-weight girls. However, in this study the females were heavier than their male counterpart though this did not manifest in differences in their FPG. The reason may have to do with the study population. Onyesom studied Nigerian undergraduates while Hossain studied Bangladeshi undergraduates.

The low FPG recorded in children $\leq 10$ years has been noted by Ibrahim ${ }^{[13]}$ and it may be due to the fact that these children had lower BMI and so lower FM and PBF than their adult counterparts. A decrease in FPG as BMI and waist circumference increase had earlier been reported by Ogbu but that is in diabetes women ( (Ogbu, I.S.I 2009; Incidence of metabolic syndrome among hospital-based patients in the University of Nigeria Teaching Hospital and apparently healthy people in Enugu metropolis an PhD thesis submitted to the University of Calabar, Nigeria).

All FPG values $\geq 6.0 \mathrm{mmol} / \mathrm{l}$ belonged to subjects older than 60 years. Disorders of glucose metabolism such as type 2 diabetes and prediabetes develop with age ${ }^{[14]}$. This may be associated with development of insulin resistance due to the replacement of body mass with visceral fat in old age ${ }^{[15-18]}$. There is increase in the number of fat cells and receptor down regulation. Visceral adiposity enhances insulin resistance and increases blood glucose ${ }^{[19-21]}$.

Conclusion.

FPG increases with age and BMI of apparently healthy subjects. The upper range of FPG values recorded is outside the reference range used for diagnosis of glucose disorder in the population. This should be noted and the age of subjects considered while interpreting FPG results in the study population. 
Age and Weight-Related Variation in Fasting Plasma Glucose among Inhabitants of Enugu Metropolis, Southeast Nigeria

Author Disclosure Statement

The authors declared no competing financial interests exist.

\section{AUTHORS' CONTRIBUTIONS}

ISIO, IAI designed the study and drafted the manuscript. BNE, OCC, ENI, UC participated in the sample collection and analysis; OES, $\mathrm{OOC}$, ONJ MN reviewed the manuscript. All authors read and approved the final version of the manuscript.

\section{REFERENCE}

1) Woolf, Z.a; Smith, A. Fasting blood glucse; Diabetes mellitus, types 2, 1; treatment: 3393. https://www.medterms.com

2) Ratini, M. Fasting blood glucose; Discovery Health; articlekey $=3472$; https://www.discovery.com

3) Juet, D.M Schole A.E. Glucose test; medlineplus. Medical encyclopaedia; 003482; http://www.nlm.nih.gov

4) Dacie, J.V; Lewis, S.M;. Practical Haematology $(1-20) .5^{\text {th }}$ Edition ELBS and Churchill Livingstone. P. 1- 20, 1975.

5) Trinder, P. Glucose enzyme (GOD/POD) method. Ann of Clin Biochem. 1969 6:24 - 27.

6) Bakari AG, Onygemelukwe GC, Sani BG, Aliyu IS, Hassan SS, Aliyu TM. Relationship between random blood sugar and body mass index in an African population. Int J Diabetes Metab. 2006; 14:144-5.

7) Panagiotakos DB, Pitsavos C, Chrysohoou C, Risvas G, Kontogianni MD, Zampelas A, et al. Epidemiology of overweight and obesity in a Greek adult population: the ATTICA Study. Obes Res. 2004; 12:1914-20.

8) McGee DI. Diverse Population Collaboration. Body mass index and mortality; a meta-analysis based on person-level data from twenty-six observational studies. Ann Epidemiol. 2005; 15:87-97.

9) Kragelund C, Hassager C, Hildebrandt P, Torp-Pedersen C, Kober L. Impact of obesity on long-term prognosis following acute myocardial infarction. Int J Cardiol. 2005; 98:123-31.

10) Onyesom Innocent ${ }^{1+}$, Oweh $O$ ThankGod ${ }^{1+}$, Etumah $O$ Sandra $^{2+}$ and Ifie $E J$ Josiah $^{1^{*}}$ Correlation between body mass index and blood glucose levels among some Nigerian undergraduates. Herbert Open Access J. Biol; 2013 2:4 DOI: http://dx.doi.org/10.7243/2050-0874-2-4

11) Md. Imam Hossain, Md. Shariful Islam, Mirza Rokibul Hasan, Moriom Akter, Md.Sadek Hosen Khoka. Fasting blood glucose level and its association with sex, body mass index and blood pressure: a cross sectional study on a Bangladeshi public university students Int/ J. of Comm Med.Pub.Health | 2017 August l; 4(8):2663-26699 http://www.ijcmph.compISSN2394$\underline{6032}$

12) Slimane Mehdad, Abdeslam Hamrani, Khalid El Kari, Asmaa El Hamdouchi, Amina Barakat, Mohamed El Mzibri, Najat Mokhtar, and Hassan Aguenaou. Body Mass Index, Waist Circumference, Body Fat, Fasting Blood Glucose in a Sample of Moroccan Adolescents Aged 11-17 Years. J. Nutri Meta., 2012, Article ID 510458, 7 pages, 2012. https://doi.org/10.1155/2012/510458

13) Ibrahim, M. Interpretation of FBG values. Pan Arab Conference of Diabetes. Vol1(1)

14) Cheesbrough, M. Medical Laboratory Manual for Tropical Countries vol. $1 ; 2^{\text {nd }}$ edition: University Press, Britain. P110 125

15) Willet, M.C; Manson, J.E; Stampfer, M.J;, Colditz, G.A; Rosner, B; Speizer, C.H; Hennekens, C.H; (1995). Weight, weight change and coronary heart disease in women: risk within the 'normal' weight range. JAMA 273: 461 - 465.

16) Colditz, G.A; Willet, W.C; Rotnitzky, A; Manson, J.E; (1995). Weight gain as a risk factor for clinical diabetes mellitus in women. Ann Intern Med. 122: $481-486$.

17) Huang, Z; Willet, W.C; Manson J.E; Rosner, B; Stampfer, M.J; Speizer, F.E; Colditz, G.A; (1998). Body weight, weight change and the risk of hypertension in women. Ann Intern Med. 128 (1): $81-88$.

18) Maclure, K.M; Hayes, K.C; Colditz, G.A; Stampfer, M.J; Speizer, F.E; Willet. W.C; (1989). Weight, diet and risk of symptomatic gallstone in middle aged women. New Engl J. Med 321 (9): $563-569$.

19) Nesto, R; (2004). C-reactive protein: its role in inflammation, type 2 diabetes and cardiovascular disease and the effect of insulin-sensitizing treatment with thiazolidinediones. Diab Med 21: $810-817$.

20) Bays, H; Mandrino, L; Defronzo, R.A; (2004). Role of the adipocyte, free fatty acid and ectopic fat in the pathogenesis of type 2 diabetes mellitus: peroxisomal proliferator-activated receptor agonists provide a rational therapeutic approach. J Clin Endocrinol Metab 89: 463 - 478.

21) Hseuh, W.A; Lyon, C.J; Quinones, M.J; (2004). Insulin resistance and the endothelium. Am J Med. 117 (1): 109 - 117. 
Age and Weight-Related Variation in Fasting Plasma Glucose among Inhabitants of Enugu Metropolis, Southeast Nigeria

Table 1: Showing variation of FPG (mean \pm SD) with age of subjects.

\begin{tabular}{|l|l|l|}
\hline Age Group (yr) & Mean FPG (mmol/l) & No of Subjects \\
\hline $1-10$ & $2.9 \pm 0.43$ & 20 \\
\hline $11-20$ & $4.1 \pm 0.60$ & 20 \\
\hline $21-30$ & $4.0 \pm 0.52$ & 20 \\
\hline $31-40$ & $4.0 \pm 0.69$ & 20 \\
\hline $41-50$ & $4.3 \pm 0.76$ & 20 \\
\hline $51-60$ & $4.5 \pm 0.87$ & 20 \\
\hline $61-70$ & $5.0 \pm 0.75$ & 20 \\
\hline $71-80$ & $6.0 \pm 1.00$ & 10 \\
\hline & & 150 \\
\hline
\end{tabular}

Table 2: Showing variation of FPG (mean $\pm S D$ ) with body mass index (BMI).

\begin{tabular}{|l|l|l|}
\hline BMI Groups & FPG $(\mathrm{mmol} / \mathrm{l})$ & No of subjects \\
\hline$<20$ & $3.3 \pm 0.66$ & 23 \\
\hline $20-25$ & $4.1 \pm 0.60$ & 47 \\
\hline $26-30$ & $4.5 \pm 0.87$ & 39 \\
\hline $31-35$ & $4.6 \pm 0.95$ & 31 \\
\hline $36-40$ & $5.1 \pm 0.90$ & 8 \\
\hline$>40$ & $6.0 \pm 0.07$ & 2 \\
\hline & & 150 \\
\hline
\end{tabular}

Table 3: Showing the distribution of test subjects with mean ranges of FPG

\begin{tabular}{|l|l|}
\hline FPG $(\mathrm{mmol} / \mathrm{l})$ & No of test Subjects \\
\hline$<2.2$ & 1 \\
\hline $2.2-3,3$ & 25 \\
\hline $3.4-4.4$ & 64 \\
\hline $4.5-5.5$ & 44 \\
\hline $5.6-6.6$ & 14 \\
\hline$>6.6$ & 2 \\
\hline
\end{tabular}

